$5 \mathrm{~cm}$. in diameter, resting on three screws, one of which has a graduated head, is movable vertically along, and rotatable about its axis, and by rotation of the graduated screw the axis of the cylinder is inclined at a known angle to the grinding lap. A crystal suitably mounted is brought by means of these two rotations into any desired position, a series of chucks of different inclinations being provided for holding it. The zero position is determined optically. A graphical method of determining the requisite rotations was described.

\title{
OOREFSPONDENOE.
}

\section{THE NATURE AND ORIGIN OF FIORDS.}

Sir,-Although Professor J. W. Gregory denies the presence of fiords in South Victoria Land in his recently published work with the above title, I feel bound to point out that fiord-valleys whose characteristics agree in all essentials with his fiord-valleys (pp. 17 and 19) occur, if somewhat infrequently.

The existence of fiord-valleys on this coast strengthens rather than weakens his main theme, and, as we are led to expect (p. 479), a simple foundering, such as that which has taken place in South Victoria Land, would not form a full fiord-system. In singling out only two of the many 'inlets' which indent the coast he implies (p. 370) that they are not eren simple fiords. The first, Tucker Inlet, has had only its entrance fixed by ships passing along the coast, and therefore it is not likely that any branches or arms, if such exist, would be indicated on the published maps; the second, Granite Harbour, lately surveyed in detail by Mr. Debenham of Scott's ill-fated expedition, in many respects would resemble a fiord were the sea to encroach 1,000 feet or so upon the land. Likewise the Ferrar Glacier and its branches, if depressed some 3,000 feet, would provide all the essential characteristics of a fiord (pp. 66 and 385), and the accompanying sketch-map is intended to depict the coastlines subsequent to such a submergence of the valley (see p. 190).

The points outlined above should have an important bearing on the subject of glacial erosion, i.e. the erosive power of water-substance in its solid form (ice), which once again is under discussion. Professor T. W. E. Darid and Mr. Priestley, after boldly showing on a map (Eleventh International Geological Congress) a network of faults determining the main tectonic features of South Victoria Land, have joined the ranks of the 'Erosionists'. (I noticed that only one of the series of east and west series of faults was made to coincide with an important east and west valley.) So too has Mr. Griffith Taylor in his contribution to the narrative of "Scott's Last Expedition"; but he does not explain why the glaciers which gouged out the valleys leading into Granite Harbour did not remove Mount Suess, nor why the ice-stream which excavated Taylor Valley (the North Fork of the Discovery and Nimrod maps) did not remove the two projecting Riegeln.

During my traverse of the then unexplored Ferrar Glacier, I, like Professor Gregory (Preface), " found it difficult to determine which 
features were due to denudation, glacial and preglacial, and which were due to valley formation by movements of the earth's crust," and hence in my report described what $I$ saw, but made no deductions. Now that $I$ have gained further knowledge and experience I feel that I can take up a definite position. I hold that the great transverse ralleys of Central South Victoria Land were not entrenched by glacial erosion, but are disruption clefts due to the unequal foundering of the land, the Royal Society Range having stood firm as the surrounding continent subsided.

I would go even a step further than Professor Gregory in denving the erosive power of ice as such. In the first place I agree with

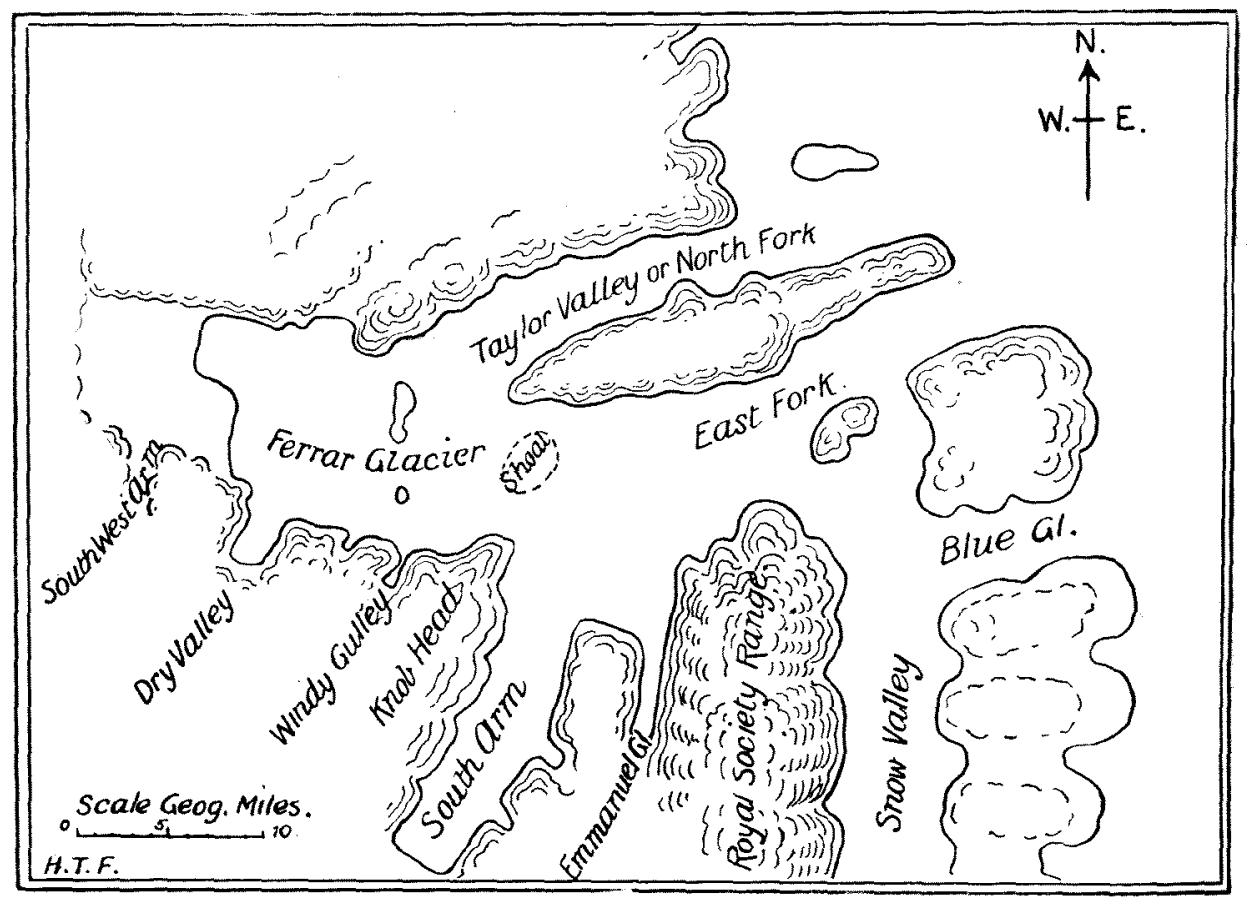

Sketch-map showing shore-lines of Ferrar Glacier and its branches after a submergence of 3,000 feet.

Professor Garwood and Dr. Harker that the corroding action of a partially buoyed up glacier snout, which is thawing above water and melting below, is small. In the second place I do not see how corrosion by pot-holing (p. 407), the evidence for which is meagre, can deepen a valley indefinitely, for unless the water of the supraglacial cascade escapes as a subglacial stream below the bed level of the valley a pool will be created and the water in it will form a cushion, and so set a limit to the process. In the third case spur-truncation seems to me to be brought about by the action of running water more than by the rasping action of rock-charged ice. Between glacier side and 
valley wall a racing stream is usually to be seen, which erodes both ice and rock. The stream cannot meander away from the valley-wall, for owing to the movement of the glacier the ice is renewed as fast as or faster than it disappears, while the spurs of the hills are open to the continuous attack of the water thus trained against them. No doubt this enhanced action of the water has given rise to the seemingly contradictory conclusion (p. 431) "that glaciers have the power of cutting back spurs which is greater than that of water".

H. T. Ferrar,

February 23, 1914.

Geologist to the Discovery Antarctic Expedition.

\section{OBITUAATY.}

SIR JOHN MURRAY, K.C.B., F.R.S., LL.D., D.Sc., Ph.D. BORN MARCH 3, 1841. DIED MARCH 16, 1914.

A FEELING of profound regret was shared by all naturalists and men of science generally at the announcement on March 17 of the sudden death by a motor accident of Sir John Murray, whose name is so intimately associated with the famous Challenger explorations, and to whose untiring energy and devotion we are indebted for the carrying out of the results of the work, a task which, owing to the illness of Sir Wyville Thomson, fell almost entirely to Sir John Murray. The Challenger sailed in December, 1872, and returned in May, 1876, bringing back innumerable pelagic and other organisms new to science. Writers of eminence in the several departments were engaged, whose labours occupied from 1880 to 1895 , resulting in the production of fifty large quarto volumes admirably illustrated by maps, plates, and text-figures. This fine series of "Challenger Reports", thanks to the efforts of Sir John Murray and the generosity of the British Government, may now be seen and consulted in all the principal libraries and scientific institutions of the world.

Born at Coburg, Ontario, Canada (March 3, 1841), John Murray was the second son of Robert Murray and his wife Isabel, daughter of the late Thomas Henderson, ship-owner. He was educated at a public school in Canada, then in 1858 at the High School of Stirling, Scotland, and later at Edinburgh University, where he came under the influence of Lord Kelvin, Clerk Maxwell, and Professor 'Tait.

Sir John Murray, in addition to his administrative and editorial duties, took an active part in the "Challenger Reports", and contributed two large volumes summarizing the scientific results of the expedition, which occupied twenty-three sears of his life. Nor was Sir John Murray's work confined to the famous Challenger expedition, for in 1880 and 1882 he took part in the exploration of the Faröe Channel in H.M.S. Knight Errant and H.M.S. Triton. He also established marine laboratories on the shores of the Forth at Granton and on the Clyde at Millport, Cumbrae. With his steam racht Medusa, fitted with all suitable appliances, he made soundings and exploration of numberless locks and straits on the coast of Scotland. (See also his and Mr. Pullar's Bathymetrical Survey of the Scottish Freshwater Locks, 6 rols., 8ro, Edinburgh, 1910.) 